\title{
Feeding of low birth weight (LBW) and very low birth weight (VLBW) Infants
}

\author{
Abbas $A^{* 1}$ \\ ${ }^{1}$ Neonatology, The Royal London Hospital, London, United Kingdom
}

\section{Background}

Feeding of Low Birth Weight (LBW) and Very Low Birth Weight (VLBW) infants remains a challenge. While enteral feeding should be the preferred method of feeding in these infants owing, the complications associated with parenteral nutrition, it is often complicated due to inherent risks these infants are predisposed to because of prematurity and low birth weight. Therefore, a balance and consistent approach is required. Our nutritional approach for these sub group of infants should be to attain weight gain and growth equivalent to that which would have occurred in utero in a normal pregnancy. In recent years, there has been a better understanding of the physiological basis of enteral nutrition in VLBW infants. We explore the current recommendations for feeding of infants in this group.

\section{Enteral nutritional requirements of preterm infants}

VLBW infants are different from their term counterparts in having been born without significant nutrient stores and having increased expenditure owing to complications inherent to prematurity like respiratory distress, hypothermia etc. Over the years' recommendations of feeding for VLBW babies have recognized the need for higher requirement of calories, protein, sodium, phosphate, calcium and other nutrients (Tables 1 and 2).

Tsang (2005) [1] and ESPHGHAN (2010) [2]provide the more recent estimates.

\section{When should enteral feeds be started}

In stable low risk infants, there is increasing evidence to start feeding on day 1 in the first few hours after birth [3].There is no consensus on when to start feeding in high risk infants, however, there is a move to start feeding early even in this group [4]. High risk infants are predisposed to developing necrotizing enterocolitis (NEC) and include infants with severe growth retardation, abnormal dopplersantenatally, extremely preterm infants and infants receiving inotropes.

Caution should also be taken when starting feeds in the following sub-groups:

- $\quad<28$ weeks gestation or $<1000$ g birth weight

- Complex congenital heart disease

- NSAID treatment for PDA

- Polycythemic infants

- Infants restablishing feeds after an episoide of NEC

- Perinatal hypoxia-ischaemia with significant organ dysfunction
- Infant with congenital gastrointestinal malformations (e.g. gastroschisis)

Unless there is a contraindication these infants can be started in trophic feeds within 48 hours of birth. The volume of trophic feeds is $0.5-1 \mathrm{ml} / \mathrm{kg} /$ hour or $12-24 \mathrm{ml} / \mathrm{kg} /$ day, the minimum amount being $0.5 \mathrm{ml} /$ hour. 5, 6

Contraindications for early trophic feeding include systemically unstable infants (e.g infants on significant inotropic support, fulminant sepsis) and suspected or confirmed intestinal obstruction or intestinal perforation. 6

\section{Increment of feeds}

Current evidence suggests once trophic feeds have been started and tolerated, feeds can be safely increased with volumes of $10-30 \mathrm{ml} / \mathrm{kg} /$ day in low risk infants $[7,8]$.Consideration must be given to gestational age and birth weight with infants on the lower end of spectrum feeds must be increased at a lesser volume compared to relatively more mature infants. Increase feeds only if clinical assessment confirms they are being tolerated. e.g. no abdominal distension, no excessive aspirates. Aspirates of $2-3 \mathrm{ml} / \mathrm{kg}$ may be acceptable, however gastric residuals and abdominal girth should not be checked routinely $[9,10]$. Persistent bile aspirates indicate ileus or rarely intestinal obstruction and feeds should be withheld in such cases.

There is less evidence on volume of advancement of feeds in high risk infants. The current recommendations are to keep these infants on trophic feeds for several days followed by slow increments of $10-20 \mathrm{ml} /$ $\mathrm{kg} /$ day, keeping a low threshold for stopping feeds if there are signs of feed intolerance or clinical instability $[11,12]$.

Table 1. Tsang (2005) [1] and ESPHGHAN (2010) [2] provide the more recent estimates.

\begin{tabular}{|c|c|c|c|c|}
\hline Nutrient & Term infant & \multicolumn{2}{|c|}{$\begin{array}{c}\text { Preterm infant } \\
\text { Tsang } 2005[1]\end{array}$} & $\begin{array}{c}\text { Preterm infant } \\
\text { ESPGHAN } \\
2010[2]\end{array}$ \\
\hline & & ELBW & VLBW & $1000 \mathrm{~g}-1800 \mathrm{~g}$ \\
\hline Energy $(\mathrm{Kcal} / \mathrm{kg})$ & $95-115$ & $130-150$ & $110-130$ & $110-135$ \\
\hline Protein $(\mathrm{g} / \mathrm{Kg})$ & 2 & $3.8-4.4$ & $3.4-4.2$ & $4.0-4.5(<1.0 \mathrm{Kg})$ \\
\hline Sodium $(\mathrm{mmol} / \mathrm{kg})$ & 1.5 & $3.0-5.0$ & $3.0-5.0$ & $3.0-5.0$ \\
\hline Potassium $(\mathrm{mmol} / \mathrm{kg})$ & 3.4 & $2.0-3.0$ & $2.0-3.0$ & $2.0-3.5$ \\
\hline Calcium $(\mathrm{mmol} / \mathrm{kg})$ & 3.8 & $2.5-5.5$ & $2.5-5.5$ & $3.0-3.5$ \\
\hline Phosphate $(\mathrm{mmol} / \mathrm{kg})$ & 2.1 & $2.0-4.5$ & $2.0-4.5$ & $1.9-2.9$ \\
\hline
\end{tabular}

Correspondence to: Asad Abbas, MBBS, MD, MRCPCH, Senior Clinical Fellow, Neonatology, The Royal London Hospital, London, United Kingdom; Tel: +447477943571; E-mail: syedabbas.asad@gmail.com

Received: February 17, 2017; Accepted: March 02, 2017; Published: March 06, 2017 
Table 2. Suggests feeding regimen based on gestation and risk groups

\begin{tabular}{|c|c|c|c|c|c|}
\hline Gesatation or other age group & Age to start feeds if well & Starting enteral volumes & Initial frequency & Rate of increase & Final Volume \\
\hline 23-25 weeks & $\begin{array}{c}\text { When stable and EBM } \\
\text { available }\end{array}$ & $10-15 \mathrm{ml} / \mathrm{kg} /$ day & Hourly & $10-15 \mathrm{ml} / \mathrm{kg} / \mathrm{dat}$ & $150-180 \mathrm{ml} / \mathrm{kg} / \mathrm{day}$ \\
\hline 26-29 weeks & $\begin{array}{c}\text { When stable and EBM } \\
\text { available }\end{array}$ & $20-25 \mathrm{ml} / \mathrm{kg} /$ day & Hourly & $20-25 \mathrm{ml} / \mathrm{kg} /$ day & $150-180 \mathrm{ml} / \mathrm{kg} /$ day \\
\hline 30-33 weeks & $3-12$ hours & $60 \mathrm{ml} / \mathrm{kg} /$ day & Hourly & $30 \mathrm{ml} / \mathrm{kg} /$ day & $150-180 \mathrm{ml} / \mathrm{kg} /$ day \\
\hline $34-36$ weeks & $<4$ hours & $60 \mathrm{ml} / \mathrm{kg} /$ day & 3 hourly & $30 \mathrm{ml} / \mathrm{kg} /$ day & $150 \mathrm{ml} / \mathrm{kg} /$ day \\
\hline Unwell preterm/High risk & $\begin{array}{l}\text { Consider when EBM } \\
\text { available or }>4 \text { days }\end{array}$ & $10-15 \mathrm{ml} / \mathrm{kg} /$ day & Hourly or 2 hourly & \multicolumn{2}{|c|}{ Minimal enteral nutrition until baby stabilizes } \\
\hline
\end{tabular}

\section{Choice of milk for first feeding}

Maternal EBM remains the first-choice milk for VLBW babies. Mothers should be actively supported in expressing milk for their babies and should be shown how to express by an experienced member of the nursing staff [13-16]. Formula milk should only be used when mother has clearly expressed that she doesn't want to breast feed, not in a position to express due to significant illness or in cases where maternal breast milk is contraindicated. Whenever possible a preterm formula should be used in such cases[17,18].

Consider fortification of breast milk when the growth is suboptimal on MEBM.

\section{Monitoring growth and nutrition}

Monitoring of growth is of vital importance in VLBW babies. Any faltering in growth should be identified early and remedial measures taken to optimize nutrition. Both anthropological and biochemical markers should be employed for monitoring. All babies should have weight and head circumference taken and recorded on growth chart on admission. Thereafter these parameters should be monitored weekly.

Length should be monitored in all preterm babies whose weight is below the $2^{\text {nd }}$ centile. Serial measurements should be taken at least monthly. Bloods for biochemical markers should be done at least weekly in VLBW infants and should include serum levels of sodium, potassium, calcium, phosphate, urea, albumin, Alkaline Phosphatase, Alanine transaminase, bilirubin and full blood counts.

\section{Minerals and micronutrients}

Preterm/LBW babies usually require more sodium and phosphate than term babies. If they are receiving pure EBM, this can be supplemented by giving sodium chloride and sodium dihydrogen phosphate. Infants receiving fortified breast milk usually receive sufficient of these nutrients and need not be supplemented.

In addition, all VLBW babies should be supplemented with multivitamins and folic acid once they reach full feeds. Iron should be added once they reach one month of age.

\section{Individualization of feeds}

Feeding in preterm/VLBW babies require understanding of the individual babies needs and we should be wary of simple answers. They are a complex, heterogeneous group and often feeding these babies is complicated by existence of one or more risk factors. Hence, while starting feeds in these babies' individual needs and risk factors should be considered carefully. If the nutritional requirements are not being met despite adequate fortification of preterm/LBW formulas dieticians should be involved in formulating feeding plans.

\section{References}

1. Tsang R C, Uauy R, Koletzko B, Zlotkin S H. Nutrition of the preterm infant: scientific basis and practical guidelines 2nd edn. Cincinnati, OH: Digital Educational Publishing2005.
2. Agostoni C, Buonocore G, Carnielli VP, De Curtis M, Darmaun et al. (2010) Enteral nutrient supply for preterm infants: commentary from the European Society of Paediatric Gastroenterology, Hepatology and Nutrition Committee on Nutrition. $J$ PediatrGastroenterolNutr50:85-91.

3. Embleton ND (2008) When should enteral feeds be started in preterm infants? Paediatr Child Health18:200-201.

4. Hans DM, Pylipow M, Long JD, Thureen PJ, Georgieff MK (2009) Nutritional practices in the neonatal intensive care unit: analysis of a 2006 neonatal nutrition survey. Pediatrics 123: 51-57.[Crossref]

5. Dunn L, Hulman S, Weiner J, Kliegman R (1988) Beneficial effects of early hypocaloric enteral feeding on neonatal gastrointestinal function: Preliminary report of a randomized trial. JPediatr112:622-629.[Crossref]

6. Meetze WH, Valentine C, McGuigan JE, Conlon M, Sacks N, et al. (1992) Gastrointestinal priming prior to full enteral nutrition in very low birth weight infants. J PediatrGastroenterolNutr15:163-170.[Crossref]

7. McGuire W, Bombell S (2008) Slow advancement of enteral feed volumes to prevent necrotising enterocolitis in very low birth weight infants. Cochrane Database Syst Rev2:CD001241.

8. Churella HR, Bachhuber WL, MacLean WC Jr (1985) Survey: methods of feeding lowbirth-weight infants. Pediatrics76: 243-249.[Crossref]

9. Malhotra AK, Deorari AK, Paul VK, Bagga A, Singh M (1992) Gastric residuals in preterm babies. J Trop Pediatr38: 262-264.[Crossref]

10. Bhatia P, Johnson KJ, Bell EF (1990) Variability of abdominal circumference of premature infants. J. PediatrSurg25:543-544.[Crossref]

11. Kempley S, Gupta N, Linsell L, Dorling J, McCormick K, et al. (2013) Feeding infants below 29 weeks' gestation with abnormal antenatal Doppler: Arch Dis Child Fetal Neonatal Ed99: F6-F11. [Crossref]

12. King C (2010) What's new in enterally feeding the preterm infant? Arch Dis Child Fetal Neonatal Ed 95: F304-308.[Crossref]

13. Sisk PM, Lovelady CA, Gruber KJ, Dillard RG, O'Shea TM (2008) Human milk consumption and full enteral feeding among infants who weigh Pediatrics 121: e15281533.[Crossref]

14. Meinzen-Derr J, Poindexter B, Wrage L, Morrow AL, Stoll B, et al. (2009) Role of human milk in extremely low birth weight infants' risk of necrotizing enterocolitis or death. J Perinatol29: 57-62.[Crossref]

15. Sisk PM, Lovelady CA, Dillard RG, Gruber KJ, O’Shea TM (2007) Early human milk feeding is associated with a lower risk of necrotizing enterocolitis in very low birth weight infants. J Perinatol27: 428-433.[Crossref]

16. Rønnestad A, Abrahamsen TG, Medbø S (2005) Late-onset septicemia in a Norwegian national cohort of extremely premature infants receiving very early full human milk feeding. Pediatrics 115:e269-76.[Crossref]

17. Florendo KN, Bellflower B, van Zwol A (2009) Growth in preterm infants fed either a partiallyhydrolyzed whey or an intact casein/whey preterm infant formula. $J$ Perinatol29:106-111. [Crossref]

18. Mihatsch WA, von Schoenaich P, Fahnenstich H (2001) Randomized, multicenter trial of two different formulas for very early enteral feeding advancement in extremely-lowbirth-weight infants. J PediatrGastroenterolNutr33:155-159. [Crossref]

Copyright: (C2017 Abbas A. This is an open-access article distributed under the terms of the Creative Commons Attribution License, which permits unrestricted use, distribution, and reproduction in any medium, provided the original author and source are credited. 